\title{
Simultaneous Detection of Mastitis Pathogens, Staphylococcus aureus, Streptococcus uberis, and Streptococcus agalactiae by Multiplex Real-Time Polymerase Chain Reaction
}

\author{
B. E. Gillespie and S. P. Oliver \\ Food Safety Center of Excellence, Department of Animal Science, \\ The University of Tennessee, Knoxville 37996
}

\section{ABSTRACT}

The objective of this study was to develop a multiplex real-time polymerase chain reaction (PCR) method for simultaneous detection of Staphylococcus aureus, Streptococcus agalactiae, and Streptococcus uberis directly from milk. A genetic marker specific for Staph. aureus was used for primers and dual-labeled probe design. The target for Strep. agalactiae primers and dual-labeled probe was selected from the $c f b$ gene encoding the Christie-Atkins-Munch-Petersen factor. The plasminogen activator gene was the target for primers and dual-labeled probe design for Strep. $u b$ eris. Quarter milk samples $(\mathrm{n}=192)$ were analyzed by the multiplex real-time PCR assay and conventional microbiological methods. An additional 57 quarter milk samples were analyzed in a separate real-time PCR assay for Strep. agalactiae only. Using an overnight enrichment step, the real-time PCR technique correctly identified $96.4 \%$ of all quarter milk samples; $91.7 \%$ of Staph. aureus, $98.2 \%$ of Strep. agalactiae, and $100 \%$ of Strep. uberis. Results of conventional microbiological methods were used to determine the sensitivity and specificity of the multiplex real-time PCR procedure. The sensitivity of the procedure to correctly identify Staph. aureus, Strep. agalactiae, and Strep. uberis directly from milk was $95.5 \%$, and the specificity was $99.6 \%$. Results of this study indicate that the multiplex real-time PCR procedure has the potential to be a valuable diagnostic technique for simultaneous identification of Staph. aureus, Strep. agalactiae, and Strep. uberis directly from quarter milk samples.

(Key words: multiplex real-time polymerase chain reaction, Staphylococcus aureus, Streptococcus agalactiae, Streptococcus uberis)

Abbreviation key: ATCC = American Type Culture Collection, CAMP = Christie-Atkins-Munch-Petersen,

Received March 6, 2005.

Accepted June 10, 2005.

Corresponding author: S. P. Oliver; e-mail: soliver@utk.edu.
CPS = coagulase-positive Staphylococcus, $\mathbf{C}_{\mathbf{T}}=$ cycle threshold.

\section{INTRODUCTION}

Worldwide, mastitis is the most common infectious disease affecting dairy cows and the most economically important disease of the dairy industry. Several bacteria are implicated including Staphylococcus aureus, Streptococcus agalactiae, and Streptococcus uberis (Oliver et al., 1997). Identification of a bacterial pathogen in milk from a cow with mastitis is regarded as the definitive diagnosis of an IMI. Identification of mastitis pathogens is generally performed by traditional culture followed by biochemical tests on bacterial isolates (Oliver et al., 2004). Conventional microbiological methods have been the gold standard for identification of bacteria from milk. Identification of bacteria in most clinical laboratories is currently based on analysis of phenotypic characteristics utilizing biochemical tests, serotyping, and enzymatic profiles. Advantages associated with conventional culture methods are that viable bacteria can be identified as the causative agent of mastitis and antimicrobial susceptibilities can be performed providing information for selection of appropriate antimicrobial therapy. However, there are several disadvantages associated with current microbiological methods. A negative culture may result from residual antibiotics following antibiotic therapy or from low numbers of pathogens in the sample. Presence of leukocytes in milk from cases of clinical mastitis may also result in negative culture results (Phuektes et al., 2001). Current methods of mastitis pathogen identification are time consuming; identification of most pathogens by standard biochemical methods generally requires more than $48 \mathrm{~h}$ to complete. Inadequate pathogen detection or confirmation techniques have often delayed timely intervention in disease control intervention.

Use of DNA-based assays may circumvent some of the problems associated with conventional microbiological procedures. Perhaps the greatest single advantage of DNA-based diagnostic assays is that these 
methods focus on the unique nucleic acid composition of the bacterial genome rather than on phenotypic expression of products that nucleic acids encode. Therefore, DNA-based identification assays are subject to less variability compared with diagnostic methods based on phenotypic characterization. The DNA-based identification systems are targeted for specific pathogens, allow for rapid screening of a large number of pathogens simultaneously, and provide definitive confirmation of pathogens. Polymerase chain reaction protocols have been developed for identification of various mastitis pathogens (Jayarao et al., 1996; Forsman et al., 1997; Kim et al., 2001; Riffon et al., 2001; Daly et al., 2002; Meiri-Bendek et al., 2002; Phuektes et al., 2001, 2003). These PCR methods allow identification of bacteria within hours. With the use of real-time PCR, time for identification of bacteria directly from mastitis samples could be further reduced.

Real-time PCR utilizes the 5'-3' nuclease activity of Taq DNA polymerase to digest an internal fluorogenic probe labeled with a fluorescent reporter dye and a fluorescent quencher dye (Cai et al., 2003). During amplification, the probe is hydrolyzed relieving the quenching of the reporter dye, resulting in an increase in fluorescent intensity. This change in reporter dye fluorescence is quantitative for PCR product, and under appropriate conditions, for template. Such methods would be even more useful if they could be finetuned to simultaneously detect and quantify a mixture of pathogens in a sample. The objective of the present study was to develop a multiplex real-time PCR method to simultaneously detect common mastitis pathogens including Staph. aureus, Strep. agalactiae, and Strep. uberis directly from milk.

\section{MATERIALS AND METHODS}

\section{Milk Samples}

Quarter milk samples $(\mathrm{n}=192)$ were collected from dairy cows from dairy research herds of The University of Tennessee. These samples were collected before milking using standard procedures described by the National Mastitis Council (Oliver et al., 2004). Before sample collection, teats of cows were dipped with a premilking teat disinfectant, cleaned thoroughly, and dried with individual disposable paper towels, and teat ends were sanitized with swabs containing $70 \%$ isopropyl alcohol. Milk samples were transported on ice, frozen, and maintained at $-20^{\circ} \mathrm{C}$ until analysis. The University of Tennessee dairy research herds were free of Strep. agalactiae. Quarter milk samples $(\mathrm{n}=57)$ previously identified as Strep. agalactiae-positive were obtained from Cornell University (Ithaca, NY). These Strep. agalactiae-positive samples were used in devel- oping the real-time PCR assay for detection of Strep. agalactiae.

\section{Conventional Microbiological Analysis}

Milk samples were examined following procedures recommended by the National Mastitis Council (Hogan et al., 1999; Oliver et al., 2004). Briefly, $10 \mu \mathrm{L}$ of foremilk was plated onto one quadrant of a trypticase soy agar plate supplemented with 5\% defibrinated sheep blood (Becton Dickinson Co., Franklin Lakes, $\mathrm{NJ})$. Plates were incubated at $37^{\circ} \mathrm{C}$ and bacterial growth was observed at 24-h intervals for $3 \mathrm{~d}$. Bacteria on primary culture medium were identified tentatively according to colony morphologic features, hemolytic characteristics, and catalase test. Isolates identified presumptively as staphylococci were tested for coagulase by the tube coagulase method, mannitol salt (Becton Dickinson), and DNase agar (Becton Dickinson). Isolates identified presumptively as streptococci were evaluated for growth in $6.5 \% \mathrm{NaCl}$, hydrolysis of esculin, and Christie, Atkins, and Munch-Petersen (CAMP)-reaction. Streptococcal organisms were identified to the species level using the API 20 Strep System (bioMérieux Inc., Hazelwood, MO). Gram-negative isolates were evaluated by their biochemical reactions on the following: MacConkey agar (Becton Dickinson), triple sugar iron agar (Becton Dickinson), urea agar (Becton Dickinson), oxidase (Becton Dickinson), motility, indole, and ornithine decarboxylase (Becton Dickinson), and identified to the species level using the API 20E System (bioMérieux Inc.).

\section{Bacterial Strains}

American Type Culture Collection (ATCC, Manassas, VA) reference strains used as positive controls for the multiplex real-time PCR assay included Staph. aureus (ATCC 10832), Strep. agalactiae (ATCC 27956), and Strep. uberis (ATCC 27958). Fifty-three different ATCC reference strains were used in the cross-reactivity study including: 11 Staphylococcus strains, 9 Streptococcus strains, 4 Enterococcus strains, 1 Aerococcus strain, 5 Listeria strains, 2 Pseudomonas strains, and 21 strains from the Enterobacteriaceae family (Table 1). An additional 25 Strep. $u b$ eris CAMP-positive strains were used for cross-reactivity with Strep. agalactiae specific primers and duallabeled probe that targeted the $c f b$ gene encoding the CAMP factor.

\section{DNA Isolation}

Bacterial DNA was extracted directly from reference strains and CAMP-positive Strep. uberis strains using 
Table 1. Bacterial strains evaluated for specificity by multiplex real-time PCR for detection of Staphylococcus aureus, Streptococcus agalactiae, and Streptococcus uberis.

\begin{tabular}{|c|c|c|c|c|}
\hline Bacterial strain & $\begin{array}{l}\text { Source/ } \\
\text { ATCC }^{1} \\
\text { no. }\end{array}$ & $\begin{array}{l}\text { Staph. } \\
\text { aureus- } \\
\text { specific } \\
\text { probe }\end{array}$ & $\begin{array}{l}\text { Strep. } \\
\text { agalactiae- } \\
\text { specific } \\
\text { probe }\end{array}$ & $\begin{array}{l}\text { Strep. } \\
\text { uberis- } \\
\text { specific } \\
\text { probe }\end{array}$ \\
\hline Staphylococcus aureus ssp. aureus & 10832 & Positive & Negative & Negative \\
\hline Staphylococcus aureus ssp. aureus & 13709 & Positive & Negative & Negative \\
\hline Staphylococcus aureus ssp. aureus & 29213 & Positive & Negative & Negative \\
\hline Staphylococcus warneri & 27836 & Negative & Negative & Negative \\
\hline Staphylococcus cohnii ssp. cohnii & 35622 & Negative & Negative & Negative \\
\hline Staphylococcus hominis ssp. hominis & 27844 & Negative & Negative & Negative \\
\hline Staphylococcus simulans & 27848 & Negative & Negative & Negative \\
\hline Staphylococcus epidermidis & 14990 & Negative & Negative & Negative \\
\hline Staphylococcus chromogenes & 43764 & Negative & Negative & Negative \\
\hline Staphylococcus capitis ssp. capitis & 35661 & Negative & Negative & Negative \\
\hline Staphylococcus xylosus & 35663 & Negative & Negative & Negative \\
\hline Enterococcus faecalis & 27959 & Negative & Negative & Negative \\
\hline Enterococcus faecalis & 29212 & Negative & Negative & Negative \\
\hline Enterococcus faecium & 35667 & Negative & Negative & Negative \\
\hline Enterococcus avium & 14025 & Negative & Negative & Negative \\
\hline Aerococcus viridans & 11563 & Negative & Negative & Negative \\
\hline Strep. dysgalactiae ssp. dysgalactiae & 27957 & Negative & Negative & Negative \\
\hline Strep. dysgalactiae ssp. equisimilis & 35666 & Negative & Negative & Negative \\
\hline Streptococcus salivarius & 13419 & Negative & Negative & Negative \\
\hline Streptococcus mitis & 9811 & Negative & Negative & Negative \\
\hline Streptococcus bovis & 27960 & Negative & Negative & Negative \\
\hline Streptococcus agalactiae & 27956 & Negative & Positive & Negative \\
\hline Streptococcus parauberis & 13386 & Negative & Negative & Negative \\
\hline Streptococcus uberis & 13387 & Negative & Negative & Positive \\
\hline Streptococcus uberis & 27958 & Negative & Negative & Positive \\
\hline Listeria monocytogenes & 15313 & Negative & Negative & Negative \\
\hline Listeria innocua & 33090 & Negative & Negative & Negative \\
\hline Listeria welshimeri & 35897 & Negative & Negative & Negative \\
\hline Listeria grayi & 25401 & Negative & Negative & Negative \\
\hline Listeria ivanonii ssp. ivanonii & 19119 & Negative & Negative & Negative \\
\hline Salmonella Newport & 6962 & Negative & Negative & Negative \\
\hline Salmonella Enteriditis & 13076 & Negative & Negative & Negative \\
\hline Salmonella Typhimurium & 14028 & Negative & Negative & Negative \\
\hline Salmonella Paratyphi A & 11511 & Negative & Negative & Negative \\
\hline Salmonella Muchen & 8388 & Negative & Negative & Negative \\
\hline Salmonella Anatum & 9270 & Negative & Negative & Negative \\
\hline Salmonella Montevideo & 8387 & Negative & Negative & Negative \\
\hline Salmonella Choleraesuis & 13312 & Negative & Negative & Negative \\
\hline Salmonella Worthington & 9607 & Negative & Negative & Negative \\
\hline Pseudomonas aeruginosa & 35554 & Negative & Negative & Negative \\
\hline Pseudomonas. aeruginosa & 35422 & Negative & Negative & Negative \\
\hline Klebsiella pneumoniae & 12014 & Negative & Negative & Negative \\
\hline Klebsiella pneumoniae & 13883 & Negative & Negative & Negative \\
\hline Escherichia coli & 4350 & Negative & Negative & Negative \\
\hline Escherichia coli & 31619 & Negative & Negative & Negative \\
\hline Escherichia coli & 23545 & Negative & Negative & Negative \\
\hline Escherichia coli & 25922 & Negative & Negative & Negative \\
\hline Proteus vulgaris & 13315 & Negative & Negative & Negative \\
\hline Proteus mirabilis & 25659 & Negative & Negative & Negative \\
\hline Proteus mirabilis & 12453 & Negative & Negative & Negative \\
\hline Enterobacter cloacae & 961 & Negative & Negative & Negative \\
\hline Serratia marcescens & 13880 & Negative & Negative & Negative \\
\hline Shigella flexneri & 12022 & Negative & Negative & Negative \\
\hline Strep. uberis, CAMP-positive ${ }^{3}(\mathrm{n}=29)$ & $\mathrm{UT}^{2}$ & Negative & Negative & Positive \\
\hline
\end{tabular}

${ }^{1}$ American Type Culture Collection.

${ }^{2}$ University of Tennessee collection.

${ }^{3} \mathrm{CAMP}=$ Christie-Atkins-Munch-Petersen.

the PrepMan Ultra sample preparation reagent (Applied Biosystems, Foster City, CA). A loopful of bacterial cells was suspended in $200 \mu \mathrm{L}$ of PrepMan Ultra sample preparation reagent in a $1.5-\mathrm{mL}$ microcentrifuge tube. The sample was vortexed and heated for $10 \mathrm{~min}$ at $100^{\circ} \mathrm{C}$. After incubation, the sample was 
Table 2. Primers and dual-labeled probes for multiplex real-time PCR.

\begin{tabular}{|c|c|c|c|}
\hline Name & Sequence & $\begin{array}{l}\text { Length, } \\
\text { bp }\end{array}$ & $\begin{array}{l}\text { Fluorescent dye } \\
\text { Reporter/Quencher }\end{array}$ \\
\hline Staphylococcus aureus forward & TCAACGATATTCTTCACGACTAA & 23 & \\
\hline Staph. aureus reverse & CCAGCTTCGGTACTACTAAAG & 21 & \\
\hline Streptococcus agalactiae forward & AGCTCTATTAGAAGTACATGCT & 22 & \\
\hline Strep. agalactiae reverse & CATTTGCTGGGCTTGATTATT & 21 & \\
\hline Strep. agalactiae probe & ATCAAGTGACAACTCCACAAGTGGTAA & 27 & $5^{\prime \prime}$ TexasRed $/ 3^{\prime} \mathrm{BHQ}^{2}$ \\
\hline Streptococcus uberis forward & AGAGGAATTCATCATGTTTTAACA & 24 & \\
\hline
\end{tabular}

${ }^{1} 5^{\prime} \mathrm{FAM} / \mathrm{3}^{\prime} \mathrm{BHQ} 2$ = 6-Carboxyfluorescein / Black Hole Quencher 2.

${ }^{2} 5^{\prime}$ TexasRed/3'BHQ1 = Texas Red/ Black Hole Quencher 1.

${ }^{3} 5^{\prime} \mathrm{CY} 5 / 3$ 'BHQ2 = Cyanine5/Black Hole Quencher 2.

centrifuged for $3 \mathrm{~min}$ at $16,000 \times \mathrm{g}$. The supernatant was transferred to a new microcentrifuge tube, and 5 $\mu \mathrm{L}$ was used as DNA template for the multiplex realtime PCR assay.

For isolation of bacterial DNA directly from milk, the method described by Allmann et al. (1995) was used with modifications as described by Hein et al. (2001). Milk samples (1 mL) were enriched with tryptic soy broth (1 mL, Becton Dickinson) and incubated at $37^{\circ} \mathrm{C}$ overnight. One milliliter of enriched sample was mixed with $130 \mu \mathrm{L}$ of digestion buffer $(100 \mathrm{~m} M$ Tris, $100 \mathrm{~m} M$ EDTA, 0.5\% SDS, pH 8.0) and digested with $100 \mu \mathrm{L}$ of pronase $(10 \mathrm{mg} / \mathrm{mL}$; Sigma-Aldrich, St. Louis, MO) at $40^{\circ} \mathrm{C}$ for $3 \mathrm{~h}$. Bacterial cells were pelleted by centrifugation at $2500 \times g$ for $5 \min$ at $4^{\circ} \mathrm{C}$, and the fat layer and aqueous phase discarded. The pellet was washed 2 to 3 times with Tris-EDTA buffer $(10 \mathrm{mM}$ Tris, $1 \mathrm{~m} M$ EDTA, $\mathrm{pH}$ 7.5). Lysozyme $(100 \mu \mathrm{L}, 2.0$ $\mathrm{mg} / \mathrm{mL}$; Sigma-Aldrich) was added to the pellet and incubated for $15 \mathrm{~min}$ at room temperature $\left(22^{\circ} \mathrm{C}\right)$. After incubation, $10 \mu \mathrm{L}$ of proteinase $\mathrm{K}(20 \mathrm{mg} / \mathrm{mL}$; Roche Molecular Biochemicals, Indianapolis, IN) was added to each tube and incubated at $60^{\circ} \mathrm{C}$ for 45 to 60 min. The sample was vortexed and incubated at $95^{\circ} \mathrm{C}$ for $15 \mathrm{~min}$, and then centrifuged at $16,000 \times \mathrm{g}$ for 5 min at $4^{\circ} \mathrm{C}$ to remove cell debris. The supernatant was transferred to a new microcentrifuge tube, and $5 \mu \mathrm{L}$ was used as DNA template for the multiplex real-time PCR assay.

\section{Primers and Dual-Labeled Probes}

Primers and dual-labeled probes were designed using Beacon Designer 2.1 (Premier Biosoft International, Palo Alto, CA) and purchased from IDT (Coralville, IA). Primers and dual-labeled probes were developed for single real-time PCR assays and tested for specificity and sensitivity previously in this laboratory. Table 2 lists the sequence for each primer pair, dual-labeled probe, and fluorescent dyes attached to dual-labeled probes. For detection of Staph. aureus, a genetic marker specific for Staph. aureus was designed based on primers used by Reischl et al. (2000) that amplified a 179-bp fragment within a Staph. aureusspecific genomic marker described previously by Martineau et al. (1998). Primers amplified a 160-bp fragment within the 179-bp fragment used by Reischl et al. (2000) and the dual-labeled probe hybridized to a 28-bp fragment within the 160-bp fragment. For Strep. agalactiae, the $c f b$ gene encoding the CAMP factor was the target for Strep. agalactiae primers and probe (Ke et al., 2000). Primers were designed to amplify an 84bp fragment within the 153-bp fragment designed by Ke et al. (2000), and the dual-labeled probe used in this study was a 27-bp fragment within the 84-bp fragment. For Strep. uberis, the plasminogen activator gene described by Sazonova et al. (2001) was the target. Primers were designed to amplify a 93-bp fragment of the plasminogen activator gene and the duallabeled probe hybridized a 23-bp fragment within the 93-bp fragment.

\section{Real-Time PCR Assay}

The iQ Supermix (BioRad, Hercules, CA) was used for the multiplex real-time PCR assay. Each reaction contained $25 \mu \mathrm{L}$ of iQ Supermix (BioRad; $100 \mathrm{mM} \mathrm{KCl}$, $40 \mathrm{~m} M$ Tris-HCl, $\mathrm{pH}$ 8.4, $1.6 \mathrm{~m} M$ dNTP mix, 50 units/ $\mathrm{mL}$ of iTaq DNA polymerase, and $6 \mathrm{mM} \mathrm{MgCl} 2$ ), $2 \mu \mathrm{L}$ of $50 \mathrm{mM} \mathrm{MgCl}, 200 \mathrm{nmol}$ of each primer and duallabeled probe, and sterile water to bring the total volume to $50 \mu \mathrm{L}$. The iCycler iQ real-time PCR detection system (BioRad) was programmed for $95^{\circ} \mathrm{C}$ for $2 \mathrm{~min}$ followed by 40 repeats of $95^{\circ} \mathrm{C}$ for $15 \mathrm{~s}$ and $57^{\circ} \mathrm{C}$ for $45 \mathrm{~s}$. The fluorescence for each probe was measured during the $45-\mathrm{s}$ hold at $57^{\circ} \mathrm{C}$. For each sample, a cycle threshold $\left(\mathbf{C}_{\mathbf{T}}\right)$ was calculated based on the baseline cycles and threshold value which is 10 times the mean 
standard deviation of fluorescence in all wells over baseline cycles.

\section{Detection Limit of Multiplex Real-Time PCR Assay from Pure Culture}

Overnight cultures of Staph. aureus (ATCC 10832), Strep. agalactiae (ATCC 27956), and Strep. uberis (ATCC 27958) were used to prepare 10-fold serial dilution in UHT milk purchased from a local grocery store. Bacterial DNA was extracted directly from milk using modifications of the method described by Allmann et al. (1995), with modifications as described by Hein et al. (2001). The DNA from 10-fold dilutions was used as template for determining the sensitivity of the multiplex real-time PCR assay.

\section{Enrichment vs. Nonenrichment of Milk Samples}

Quarter milk samples $(n=20)$ were evaluated to determine if enrichment of milk samples was necessary for detection of pathogens in low numbers. For the enriched samples, $1 \mathrm{~mL}$ of trypticase soy broth (Becton Dickinson) was added to $1 \mathrm{~mL}$ of milk, mixed, and incubated overnight at $37^{\circ} \mathrm{C}$. After incubation, 1 $\mathrm{mL}$ of enriched sample was used for isolation of bacterial DNA directly from milk using the method described by Allmann et al. (1995) with modifications as described by Hein et al. (2001). For the nonenriched sample, $1 \mathrm{~mL}$ of milk was used for bacterial DNA isolation as described previously for the enriched sample. Conventional bacterial methods were conducted on the 20 samples to identify bacteria and to determine the number of colony forming units per milliliter. Results were compared to determine the sensitivity of the realtime PCR assay to identify bacteria from milk samples of enriched vs. nonenriched samples.

\section{Determination of Sensitivity and Specificity}

Sensitivity and specificity of the multiplex real-time PCR was determined using the following formulas (Martin, 1984):

Sensitivity $\%=$ true positive samples/(true positive samples + false negative samples) $\times$ 100

Specificity $\%=$ true negative samples/(true negative samples + false positive samples) $\times 100$.

\section{RESULTS}

\section{Specificity of PCR Primers and Probes}

To check the specificity of primers and dual-labeled probes for real-time PCR analysis, DNA from pure cultures of 53 type strains, and 25 Strep. uberis CAMPpositive strains was examined (Table 1). Only Staph. aureus strains tested positive in the real-time PCR assay with primers and probes specific for Staph. aureus and produced mean $\mathrm{C}_{\mathrm{T}}$ values of $19.9 \pm 0.9$. For primers and probe specific for Strep. uberis, only Strep. uberis strains were positive in the real-time PCR assay and produced mean $\mathrm{C}_{\mathrm{T}}$ values of $11.3 \pm 0.5$. Only Strep. agalactiae strains tested positive in the real-time PCR assay with primers and probes specific for Strep. agalactiae and produced mean $\mathrm{C}_{\mathrm{T}}$ values of $16.1 \pm 0.5$. Amplification of DNA from other bacterial strains evaluated either resulted in no fluorescence or a mean $\mathrm{C}_{\mathrm{T}}$ value of $>30$. Primers and probes were specific for the target organism with real-time PCR and did not show any cross-reactivity with other bacterial species.

\section{Sensitivity and Detection Limits Using Pure Cultures}

Overnight cultures of Staph. aureus (ATCC 10832), Strep. agalactiae (ATCC 27956), and Strep. uberis (ATCC 27958) were used to prepare 10-fold serial dilutions in UHT milk with bacterial concentrations ranging from $10^{0}$ to $10^{8} \mathrm{cfu} / \mathrm{mL}$. Standard curves were constructed using mean $\mathrm{C}_{\mathrm{T}}$ and bacterial $\mathrm{cfu} / \mathrm{mL}$. A linear relationship between $\mathrm{C}_{\mathrm{T}}$ and log input DNA for each bacterium was observed. However, the minimum level of detection for Staph. aureus was $10^{3} \mathrm{cfu} / \mathrm{mL}$, and for Strep. agalactiae and Strep. uberis, it was $10^{2} \mathrm{cfu} / \mathrm{mL}$. After addition of an enrichment step, the minimum level of detection was lowered to $10^{0} \mathrm{cfu} / \mathrm{mL}$ for Staph. aureus, Strep. agalactiae, and Strep. uberis.

\section{Enrichment vs. Nonenrichment of Milk Samples}

Twenty milk samples were evaluated with the realtime PCR method using enriched and nonenriched milk samples. Samples were chosen that contained Staph. aureus or Strep. uberis, or a mixture, with quantities ranging from 200 to $>10,000 \mathrm{cfu} / \mathrm{mL}$. Of the 20 milk samples, 10 were Staph. aureus-positive and 11 were Strep. uberis-positive; 1 milk sample was positive for both Staph. aureus and Strep. uberis. The realtime PCR assay using enriched milk samples was able to detect 9 of 10 Staph. aureus samples with a mean $\mathrm{C}_{\mathrm{T}}$ value of 21.5 , and 11 of 11 Strep. uberis samples with a mean $\mathrm{C}_{\mathrm{T}}$ value of 19.3. Using nonenriched samples, the real-time PCR assay was only able to detect 5 of 10 Staph. aureus samples (mean $\mathrm{C}_{\mathrm{T}}$ value of 32.1) and 10 of 11 Strep. uberis samples (mean $\mathrm{C}_{\mathrm{T}}$ value of 30.3). The 1 Staph. aureus milk sample that was negative by both enrichment and nonenrichment was positive for Staph. aureus by real-time PCR when DNA 
was isolated from the bacteria. This particular sample also contained Strep. uberis. Milk samples positive for Staph. aureus and Strep. uberis by conventional methods, but negative with real-time PCR using nonenriched milk contained 400 to $10,000 \mathrm{cfu} / \mathrm{mL}$ of Staph. aureus or Strep. uberis. Results indicate that enrichment is needed to detect low numbers of bacteria in milk. Enrichment may also be necessary to dilute inhibitory substances present in milk because the detection limit for this multiplex real-time PCR using nonenriched milk samples was $10^{3} \mathrm{cfu} / \mathrm{mL}$ for Staph. aureus and $10^{2} \mathrm{cfu} / \mathrm{mL}$ for Strep. uberis.

\section{Quarter Milk Samples}

A single real-time PCR assay for the Strep. agalactiae $c f b$ gene was performed on 57 quarter milk samples previously identified as Strep. agalactiae-positive by conventional methods. The single real-time PCR correctly identified $98.2 \%$ (56/57) quarter milk samples positive for Strep. agalactiae. The 57 quarter milk samples were used to develop the Strep. agalactiae real-time PCR assay before developing the multiplex real-time assay for Staph. aureus, Strep. agalactiae, and Strep. uberis. The remaining milk sample was not of sufficient quantity to be used in evaluation of the multiplex real-time PCR assay.

Quarter milk samples $(\mathrm{n}=192)$ screened previously by conventional microbiological methods were evaluated by the multiplex real-time PCR method for detection of Staph. aureus, Strep. agalactiae, and Strep. uberis. The multiplex real-time PCR analysis, including enrichment and DNA purification, was repeated twice for each quarter milk sample. This assay correctly identified $96.4 \%$ (185/192) of all quarter milk samples (Table 3). The multiplex real-time PCR correctly identified $91.7 \%$ of Staph. aureus, and $100 \%$ of Strep. uberis. Using the formula described by Martin (1984), the sensitivity of this procedure to correctly identify Staph. aureus, Strep. agalactiae, and Strep. uberis directly from milk was $95.5 \%$, and the specificity was $99.6 \%$.

This assay detected the target pathogen even though the sample contained more than one type of bacteria. Forty-four (Table 3) milk samples contained 2 different bacteria. The multiplex real-time PCR assay was able to identify all (15/15) milk samples that contained Strep. uberis and other bacteria including CNS, Staph. aureus, Strep. dysgalactiae, Escherichia coli, Klebsiella pneumoniae, and Serratia liquefaciens (Table 3). The multiplex real-time PCR assay was able to identify 10 of 13 milk samples that contained Staph. aureus and other bacteria including CNS, Cornyebacterium bovis, Streptomyces spp., Enterococcus faecalis, and Strep. dysgalactiae (Table 3).

The assay was able to differentiate Staph. aureus from other coagulase-positive Staphylococcus (CPS) species. Five isolates identified as CPS by conventional microbiological methods (coagulase-positive, mannitol-negative, and DNase-negative) were negative by real-time PCR of the bacterial isolate for Staph. aureus and by the multiplex real-time PCR directly from milk. Two Staph. aureus milk samples from mastitis quarters were negative for Staph. aureus on repeated occasions by multiplex real-time PCR. However, analysis of the DNA extracted from the isolated bacteria alone produced positive results.

\section{DISCUSSION}

The assay described in the present study is the first to use a multiplex real-time PCR format for detection of pathogens directly from milk. Phuektes et al. (2001, 2003) developed a multiplex PCR for detection of Staph. aureus, Strep. agalactiae, Strep. dysgalactiae, and Strep. uberis that targeted $16 \mathrm{~S}$ to $23 \mathrm{~S}$ rRNA spacer regions. Sensitivity of the multiplex PCR was lower than for each individual PCR assay, and enrichment was needed to bring the threshold for detection by multiplex PCR for all bacteria assayed to $1 \mathrm{cfu} / \mathrm{mL}$. Although this assay was able to detect 4 different bacteria, there are only 6 base-pair differences between the Strep. agalactiae and Strep. dysgalactiae ssp. dysgalactiae amplified fragments, which would make interpreting results difficult. Use of the multiplex realtime PCR eliminates the need for post-PCR analysis by gel electrophoresis.

Numerous methods for isolating bacterial DNA directly from milk have been reported in the literature and involve a wide variety of substances including Chelex-100 (Kim et al., 2001), spin columns (Phuektes et al., 2001, 2003; Riffon et al., 2001), lysozyme and proteinase $\mathrm{K}$ (Meiri-Bendek et al., 2002), diatomaceous earth (Martinez et al., 2001), alkaline extraction (Daly et al., 2002), and pronase (Allmann et al., 1995; Hein et al., 2001). Several methods were evaluated in this study for isolating bacteria directly from milk. Methods that use proprietary reagents such as InstaGene Matrix (BioRad) and PrepMan Ultra reagent (Applied Biosystems) were evaluated. Although these reagents were faster and more convenient than other methods evaluated, results were not consistent and reproducible when trying to isolate bacterial DNA from milk. The method first described by Allmann et al. (1995) and modified by Hein et al. (2001) was the most consistent and reproducible method evaluated for isolation of bacteria directly from whole milk sam- 
Table 3. Results of 192 quarter milk samples evaluated by the multiplex real-time PCR for detection of Staphylococcus aureus, Streptococcus agalactiae, and Streptococcus uberis.

\begin{tabular}{|c|c|c|c|c|c|c|c|}
\hline & & \multicolumn{2}{|c|}{ Staphylococcus aureus } & \multicolumn{2}{|c|}{ Streptococcus uberis } & \multicolumn{2}{|c|}{ Streptococcus agalactiae } \\
\hline & & Positive & Negative & Positive & Negative & Positive & Negative \\
\hline CNS & 26 & $1^{1}$ & 25 & 0 & 26 & 0 & 26 \\
\hline Staph. aureus/CNS & 4 & 3 & 1 & 0 & 4 & 0 & 4 \\
\hline CNS/Strep. dysgalactiae & 2 & 0 & 2 & 0 & 2 & 0 & 2 \\
\hline $\mathrm{CPS}^{2}$ & $\overline{5}$ & 0 & 5 & 0 & 5 & 0 & 5 \\
\hline Staph. aureus & 59 & 56 & 3 & 0 & 59 & 0 & 59 \\
\hline Strep. dysgalactiae/other bacteria ${ }^{4}$ & 17 & 0 & 17 & 0 & 17 & 0 & 17 \\
\hline Negative $^{5}$ & 10 & 0 & 10 & 0 & 10 & 0 & 10 \\
\hline Strep. uberis / Strep. dysgalactiae & 2 & 0 & 2 & 2 & 0 & 0 & 2 \\
\hline Strep. uberis & 48 & 0 & 48 & 48 & 0 & 0 & 48 \\
\hline Strep. uberis / GNR ${ }^{6}$ & 3 & 0 & 3 & 3 & 0 & 0 & 3 \\
\hline Total & 192 & 67 & 125 & 63 & 129 & 0 & 192 \\
\hline
\end{tabular}

${ }^{1} \mathrm{CNS}$ positive for Staph. aureus, $\mathrm{C}_{\mathrm{T}}=20.6$.

${ }^{2} \mathrm{CPS}=$ Coagulase-positive, mannitol-negative, DNase-negative Staphylococcus.

${ }^{3}$ Cornyebacterium bovis, Streptomyces spp., Enterococcus faecalis, and Streptococcus dysgalactiae.

${ }^{4}$ Streptococcus bovis, Enterococcus spp., and Lactococcus spp.

${ }^{5}$ No growth.

${ }^{6}$ GNR = Gram-negative rod; Escherichia coli, Klebsiella pneumoniae, and Serratia liquefaciens.

ples. Casein, a major protein in milk, is composed of several similar proteins along with calcium and phosphorus that forms a casein micelle. Pronase from Streptomyces griseus has the ability to break down virtually all proteins, including casein, into their individual amino acids. Breaking down casein and the casein micelle with pronase would allow better access to the bacteria for lysis by lysozyme and proteinase $\mathrm{K}$. This method, although more time consuming than other methods, gave the most consistent and reproducible results.

Other methods to overcome PCR inhibitors present in milk involve dilution of the sample. An enrichment step was added to overcome PCR inhibition and to increase the sensitivity of the assay. With this added step, sufficient bacteria were present to allow detection of as few as $1 \mathrm{cfu} / \mathrm{mL}$. The higher sensitivity may be due to dilution of inhibitory substances in the enrichment broth and the increased number of organisms. The presence of PCR inhibitors in milk and a variety of other clinical samples such as urine, blood, and feces have been reported (Higuchi, 1989; Toye et al., 1998). Little is known about inhibitory components present in milk. In the present study, 2 milk samples that contained Staph. aureus were repeatedly negative for Staph. aureus by multiplex real-time PCR; however, DNA extracted from the bacteria isolated from the milk was positive for Staph. aureus using the same Staph. aureus-specific primers and probe (data not shown). Both of these samples were from mammary quarters with clinical mastitis, suggesting the pres- ence of a unique PCR inhibitor. These findings suggest that PCR inhibitors were present in the original sample, but not removed by either the DNA isolation procedure or the enrichment step.

Addition of an enrichment step has been reported and appears to be necessary for detecting low numbers of bacteria $(<1000 \mathrm{cfu} / \mathrm{mL})$. Meiri-Bendek et al. (2002) developed a PCR method for detection of Strep. agalactiae in milk that targeted the conserved areas within $16 \mathrm{~S}$ rRNA. The sensitivity of this assay increased from between $10^{4}$ and $10^{5}$ to $1 \mathrm{cfu} / \mathrm{mL}$ after overnight selective enrichment. Phuektes et al. (2001) needed enrichment in a multiplex PCR for detection of Staph. aureus, Strep. agalactiae, Strep. dysgalactiae, and Strep. uberis to detect levels of $1 \mathrm{cfu} / \mathrm{mL}$.

The multiplex real-time PCR assay described here used information concerning primers for Staph. aureus and Strep. agalactiae that were shown to be sensitive and specific. Primers and probes for Staph. aureus were designed within the region used by Reischl et al. (2000). Reischl et al. (2000) and Martineau et al. (1998) reported 100\% sensitivity and specificity for this particular Staph. aureus target sequence. Primers used in this study amplified a 160-bp fragment and the dual-labeled probe hybridized to a 28 bp fragment within the 160 -bp fragment. The $c f b$ gene encoding the CAMP factor was used as the genetic target for real-time PCR for detection of Strep. agalactiae. Ke et al. (2000) designed oligonucleotides after sequence comparison of the $c f b$ genes from Strep. agalactiae, Strep. uberis, and Strep. pyogenes, which re- 
vealed that the 3 genes were moderately divergent. Ke et al. (2000) evaluated 125 bacterial and fungal species and 162 strains of Strep. agalactiae. Only Strep. agalactiae strains produced an increase in fluorescence signal that indicated a positive result for Strep. agalactiae. Primers in this study were designed to amplify an 84-bp fragment within the 153-bp fragment designed by Ke et al. (2000), and the dual-labeled probe used in this study is a 27-bp fragment within the 84-bp fragment. For Strep. uberis, primers were designed to amplify a 93-bp fragment of the plasminogen activator gene and the dual-labeled probe hybridized to a 23-bp fragment within the 93-bp fragment. This is the first report of use of the plasminogen activator gene of Strep. uberis as a target for PCR reaction.

\section{CONCLUSIONS}

The multiplex real-time PCR assay for simultaneous detection of Staph. aureus, Strep. agalactiae, and Strep. uberis directly from milk described herein was developed to evaluate the potential use of multiplex real-time PCR in the diagnosis of mastitis. By utilizing an overnight enrichment step for the multiplex realtime PCR assay, the minimum level of detection was $10^{0} \mathrm{cfu} / \mathrm{mL}$ for Staph. aureus, Strep. agalactiae, and Strep. uberis. The multiplex real-time PCR takes slightly less than $24 \mathrm{~h}$ to complete compared with 36 to $48 \mathrm{~h}$ for identification by standard culture methods. The multiplex real-time PCR technique correctly identified $96.4 \%$ of all quarter milk samples, and correctly identified $91.7 \%$ of Staph. aureus, $98 \%$ of Strep. agalactiae, and $100 \%$ of Strep. uberis. The sensitivity of this procedure to correctly identify Staph. aureus, Strep. agalactiae, and Strep. uberis directly from milk was $95.5 \%$ and the specificity was $99.6 \%$. To increase the sensitivity of this assay for detection of Staph. aureus, further research is needed to identify and overcome the effects of PCR inhibitors from milk on the multiplex real-time PCR. Results of this study indicate that the multiplex real-time PCR procedure has the potential to be developed as an alternative diagnostic method for the simultaneous identification of Staph. aureus, Strep. agalactiae, and Strep. uberis directly from quarter milk samples.

\section{ACKNOWLEDGMENTS}

This study was supported by The University of Tennessee Food Safety Center of Excellence; the Tennessee Agricultural Experiment Station; and The University of Tennessee, College of Veterinary Medicine, Center of Excellence Research Program in Livestock Diseases and Human Health.

\section{REFERENCES}

Allmann, M., C. Hoefelein, E. Koppel, J. Luthy, R. Meuer, C. Niederhauser, B. Wegmuller, and U. Canadian. 1995. Polymerase chain reaction (PCR) for detection of pathogenic microorganisms in bacteriological monitoring of dairy products. Res. Microbiol. 146:85-97.

Cai, H. Y., M. Archambault, C. L. Gyles, and J. F. Prescott. 2003. Molecular genetic methods in the veterinary clinical bacteriology laboratory: Current usage and future applications. Anim. Health Res. Rev. 4:73-93.

Daly, P., T. Collier, and S. Doyle. 2002. PCR-ELISA detection of Escherichia coli in milk. Lett. Appl. Microbiol. 34:222-226.

Forsman, P., A. Tilsal-Timisjarvi, and T. Alatossava. 1997. Identification of staphylococcal and streptococcal causes of bovine mastitis using 16S-23S rRNA spacer regions. Microbiology 143:3491-3500

Hein, I., D. Klein, A. Lehner, A. Bubert, E. Brandl, and M. Wagner. 2001. Detection and quantification of the iap gene of Listeria monocytogenes and Listeria innocua by a new real-time quantitative PCR assay. Res. Microbiol. 152:37-46.

Higuchi, R. 1989. Simple and rapid preparation of samples for PCR. Pages 31-38 in PCR technology: Principles and Applications for DNA Amplification. H. A. Ehrlich, ed. Stock Press, New York, NY.

Hogan, J. S., R. N. Gonzalez, R. J. Harmon, S. C. Nickerson, S. P. Oliver, J. W. Pankey, and K. L. Smith, ed. 1999. Laboratory Handbook on Bovine Mastitis. 2nd edition. National Mastitis Council, Inc., Madison, WI.

Jayarao, B. M., B. E. Gillespie, and S. P. Oliver. 1996. Application of randomly amplified polymorphic DNA fingerprinting for species identification of bacteria isolated from bovine milk. J. Food Prot. 59:615-620.

Ke, D., C. Menard, F. J. Picard, M. Boissinot, M. Ouellette, P. H. Roy, and M. G. Bergeron. 2000. Development of conventional and real-time PCR assays for the rapid detection of Group B Streptococci. Clin. Chem. 46:324-331.

Kim, C.-H., M. Khan, D. E. Morin, W. L. Hurley, D. N. Tripathy, M. Kehrli, Jr., A. O. Oluoch, and I. Kakoma. 2001. Optimization of the PCR for detection of Staphylococcus aureus nuc gene in bovine milk. J. Dairy Sci. 84:74-83.

Martin, S. W. 1984. Estimating disease prevalence and the interpretation of screening test results. Prev. Vet. Med. 2:463-472.

Martineau, F., F. J. Picard, P. H. Roy, M. Ouellette, and M. G. Bergeron. 1998. Species-specific and ubiquitous-DNA-based assays for rapid identification of Staphylococcus aureus. J. Clin. Microbiol. 36:618-623.

Martinez, G., J. Harel, and M. Gottschalk. 2001. Specific detection by PCR of Streptococcus agalactiae in milk. Can. J. Vet. Res. 65:68-72.

Meiri-Bendek, I., E. Lipkin, A. Friedman, G. Leitnen, A. Saron, S. Friedman, and Y. Kashi. 2002. A PCR-based method for the detection of Streptococcus agalactiae in milk. J. Dairy Sci. 85:1717-1723.

Oliver, S. P., L. F. Calvinho, and R. A. Almeida. 1997. Characteristics of environmental Streptococcus species involved in mastitis. Pages 1-35 in Proc. Symposium on Udder Health Management for Environmental Streptococci. Ontario Veterinary College, Ontario, Canada.

Oliver, S. P., R. N. Gonzalez, J. S. Hogan, B. M. Jayarao, and W. E. Owens, ed. 2004. Microbiological procedures for the diagnosis of bovine udder infection and determination of milk quality. 4th edition. National Mastitis Council, Inc., Verona, WI.

Phuektes, P., G. R. Browning, G. Anderson, and P. D. Mansell. 2003. Multiplex polymerase chain reaction as a mastitis screening test for Staphylococcus aureus, Streptococcus agalactiae, Streptococcus dysgalactiae and Streptococcus uberis. J. Dairy Res. 70:149-155.

Phuektes, P., P. D. Mansell, and G. F. Browning. 2001. Multiplex polymerase chain reaction assay for simultaneous detection of 
Staphylococcus aureus and Streptococcal causes of bovine mastitis. J. Dairy Sci. 84:1140-1148.

Reischl, U., H.-J. Linde, M. Metz, B. Leppmeier, and N. Lehn. 2000. Rapid identification of methicillin-resistant Staphylococcus aureus and simultaneous species confirmation using real-time fluorescence PCR. J. Clin. Microbiol. 38:2429-2433.

Riffon, R., K. Sayasith, H. Khalil, P. Dubreuil, M. Drolet, and J. Lagace. 2001. Development of a rapid and sensitive test for identification of major pathogens in bovine mastitis by PCR. J. Clin. Microbiol. 39:2584-2589.

Sazonova, I. Y., A. K. Houng, S. A. Chowdhry, B. R. Robinson, L. Hedstrom, and G. L. Reed. 2001. The mechanism of a bacterial plasminogen activator intermediate between streptokinase and staphylokinase. J. Biol. Chem. 276:12609-12613.

Toye, B., W. Woods, M. Bobrowska, and K. Ramotar. 1998. Inhibition of PCR in genital and urine specimens submitted for Chlamydia trachomatis testing. J. Clin. Microbiol. 36:2356-2358. 